DOI: 10.1515/ausp-2017-0010

\title{
Cultural Identity Crisis inside Self-Same Culture as Reflected in György Lôrincz's Novel Sounds of the Heart
}

\author{
Erzsébet DANI \\ University of Debrecen (Debrecen, Hungary) \\ Department of Library and Information Science \\ dani.erzsebet@zimbra.inf.unideb.hu; erzsebet.dani@gmail.com
}

\begin{abstract}
After the decisive historical moment of December 1989, the "border" is open for Transylvanian Hungarians and, in the subsequent euphoria, an exodus to the mother country commences. But with the political freedom of crossing national borders, due to globalization (too), new kinds of border problems present themselves for the youth leaving their native land: border issues of small versus large community, of interpersonal relations; the gap between generations; borders between majority versus minority identity and national versus cultural identity as well. This paper is a literary analysis with special focus on contemporary social phenomena, which will examine through discussing a relevant contemporary Székely-Hungarian novel - how cultural identity can be deformed, damaged, or at least temporarily distorted when a Hungarian from beyond the border, who arrives in mother-country Hungary, will have to redefine herself/himself within a culture which, in this case, is basically one and the same. ${ }^{1}$ Can the identity-code, which was formed by, and grew strong in, the minority existence of the native land, function when s/he enters a cultural vacuum which turns out or can turn out to be another cultural maze for her or him? Can we talk about assimilation in such cases? What happens when a "rebellious" young individual's "I" identity, unsteady in the first place, is left without the conserving and protective "We" identity in the confrontation of mother-nation versus beyond-the-border cultures so that, eventually, the young woman's "I" identity will be damaged by big-city underworld (sub)culture. Or, will cultural mimicry emerge in this situation too as a strategy to help the individual retain his/her identity? We will seek answers to these questions through discussing a novel - A szív hangjai [Sounds of the Heart] - by a fine representative of contemporary Székely-Hungarian literature, György Lőrincz.
\end{abstract}

1 "Basically" stresses the common, bonding elements of mother-country Hungarian and beyondthe-border Hungarian cultures; i.e., the Hungarianness of these cultures. It does not mean that there are no diverging features when it comes to the Székelyness of székelymagyar culture - an aspect, however, which is less significant in the context of the present study. 
Keywords: cultural identity, national identity, Transylvanian literature, migration, cultural memory.

\section{Historical Background}

After December 1989, the historical turn of events opened up new vistas for Hungarians who had been forced to live beyond Hungarian borders by the tide of history. The Ceauşescu regime's communist dictatorship of more than thirty years triggered a migration of Hungarians out of Romania. The first wave of refugees, the population motion that took place in 1988-89, was a mass migration and politically motivated: it happened for the first time in communist history that the Hungarian state openly supported and received the Transylvanian refugees. Earlier practice was to deport Hungarian political refugees back to Romania. The Hungarians of Transylvania were shocked by the 1988 Romanian political decision of so-called "settlement-systematization," which would have meant a new pretext for the destruction of (primarily Hungarian) villages and, thereby, for forced assimilation. Then the large number of those who set out in the wake of the December revolution, in the spring of 1990, indicated that the fragile political situation in Romania spurred a new wave of migration (Sík 1996, 516-517).

András Sütô said about emigration that it is like internal hemorrhage, a process which is not spectacular but painful. It was especially painful as it decimated the ethnic Hungarian intelligentsia in Romania in those days. At least one-tenth of the socially sensitive ethnic Hungarian intelligentsia left the country - the social layer that was the best custodian and maintainer of Hungarian collective national identity. Thus, on the one hand, the chances of the community that remained in the homeland were lessened in several senses by migration from the country. On the other hand, across-the-border transmigration was also an escape resulting from repressive Romanian measures against the Hungarian minority. It forced those who were leaving home and homeland then - but lived the life of minority existence up to that point - into a situation in which their homegrown understanding of national identity did not always work, and the mother-country Hungarian versus beyond-the-border Hungarian relation was put in a different perspective. Several contemporary Transylvanian writers engaged this subject, and its scholarly discourse was also born in the social sciences. This time I wish to examine Székelyudvarhely author György Lőrincz's novel A szív hangjai [Sounds of the Heart], deploying the theoretical notions outlined below. 


\section{Theoretical Background}

Migration, assimilation and identity theories are indispensable for the discussion of post-1989 Transylvanian migration. Migration is a complex and multiple process. The word itself refers to people in movement inside or outside their home country, giving up their dwelling-place forever, or leaving their homeland only temporarily, with the intention to return some time. But it also refers to people who become refugees under political or economic pressure, or are forced out of their country by a civil war, or by fear of persecution. Those who are driven by a desire for adventure to seek their luck abroad also belong here (Opitz 2001, qtd. in Cseresnyés 2005, 9).

Successful integration of migrants, Milton Myron Gordon maintains, rests on the two pillars of belonging to a certain social layer and to a different ethnic group. In the absence of the latter (as is the case in the present literary example since we are talking about ethnic Hungarians from Romania flocking to Hungary), the social-structure factor will attain greater significance (Gordon 1964, qtd. in Cseresnyés 2005, 12). Political adaptation and labour-force market integration mean structural assimilation. Qualification or skill plays a prominent role in this context. However, social integration, i.e. structural assimilation, can keep "stalling" even in cases when the social structure of immigrants and receivers is similar, they speak the same language and belong to the same cultural domain. Hungarian sociology calls this phenomenon undermigration. This phenomenon is particularly important in the case of the novel to be discussed here. Successful personal, individual assimilation means: one, achieving the status position (in accord with qualification) which the immigrant finds satisfactory; two, it comprises cultural assimilation too. The former is a precondition to the success of the latter. But one characteristic feature of structural assimilation is a certain measure of willing subordination. It manifests itself in immigrants who take jobs (below the level of their qualifications) that are not attractive to citizens of the receiving country, thereby further differentiating a given layer of the receiver society. Individuals who settle down/immigrate tend to form groups, turn inward; rivalry raises its head in their ranks from time to time; not infrequently, even ethnically related immigrants show deep respect for the receiving culture and await what future brings by keeping a low profile and in passivity. But it can lead to social segregation in the long run (Cseresnyés 2005, 12-13).

Gordon's and Robert Ezra Park's (Gyurgyík 2011) influential theories are developed basically from the multicultural nature of American society; they describe ethnic relational systems that are very different from what we have in Sounds of the Heart (ethnic Hungarians from Romania immigrate to Hungary but they have been socialized in a minority existence of totalitarian Romanian subjugation), so their otherwise important typology is not relevant for us. However, 
the way John Milton Yinger expanded Gordon's theory is very useful for analyzing Lőrinczean intercultural (or, rather, Hungarian-Hungarian intracultural) patterns. Yinger regarded assimilation as a "process of boundary reduction that can occur when members of two or more societies or smaller cultural groups meet" (1981, 249). Developing Gordon's variables further, he introduced "dissimilation" as a reciprocal notion to assimilation. He breaks down the process of assmilation into subprocesses. They are cultural, structural, biological, and psychological subprocesses, called (in the same order): acculturation, integration, amalgamation and identification. They are not "stages" in that these (sub-)processes are "interdependent," they can "occur in various combinations and sequences, and each of them is reversible" (Yinger 1981, 249, 256). ${ }^{2}$ Beth Bowman Hess's model is also highly valuable for us. Hers are stages. She distinguishes five of them in the process of integration: segregation, accommodation, acculturation, assimilation and amalgamation. ${ }^{3}$

The phases of cultural integration were also theorized by Ulrich Tolksdorf. He establishes six phases. The first is the state of cultural shock (Kulturschock), characterized by a confused sense of identity and mentality. Let us immediately take note of how prominently this basic experience unfolds in the life of those Hungarians who immigrate from Transylvania to Hungary (Kapitány-Kapitány 1996, 83). In Tolksdorf's second phase of cultural contact (Kulturkontakt) cultural linkages develop, facilitated by (common) language, immigrants familiarizing themselves with the customs and values of the receiving culture. Contact leads ${ }^{4}$ to the vigorous assertion of ethnic/cultural identity, which is Tolksdorf's third

2 Acculturation is a sub-process that takes place between groups and members of groups. It can be substitutive or additive: the former replacing elements of one culture with those of the other culture, while the latter adds elements of one culture to the other without taking away; the former is weakening, the latter is enriching a given culture. Integration or structural assimilation refers "to the process of structual assimilation of persons from two or more formerly separate sub-societies into a set of shared interactions" - the latter can be personal or institutional, involving "neighbourhoods, friendship circles, and marriage" as well as economy and politics. Amalgamation is individual and/or group-level "biological assimilation" leading to mixed population. Identification or psyhological assimilation with its shifts and reversals means that "[i]ndividuals from separate groups may come to think of themselves as belonging to the same society" (Yinger 1981, 249-253).

3 Segregation is the stage of de facto or de jure isolation. Accommodation is the stage when immigrants become aware of the norms and value system of the receiving culture, but they simply accommodate themselves to those norms and values without letting them interfere with the immigrants" own norms and value system; i.e. "[t]hey adapt to the dominant culture without fully participating in it." Acculturation: immigrants accept and identify themselves with the norms and value system of the receiving culture, "but are still not admitted to more intimate social groups." Assimilation or "structural assimilation" means "entry into the dominant society through friendship and other close associations," but "strong ethnic identity" is still retained. Amalgamation occurs when "cultures or races mix to form new cultural and racial types"; e.g. through intermarriages (Hess 1988, 247-248).

4 Better to say, it "led" to cultural conflict, in fact, as Tolksdorf's theory is also a chronological survey of the European migration/integration processes during the decades following WWII. 
stage called cultural conflict (Kulturkonflikt). The fourth step means asserting ethnic/migrant cultural identity by reaching back to cultural heritage and creating organizations and associations at regional and national levels - a development theorized by Tolksdorf as secondary minority formation (Sekundäre Minderheitenbildung). The fifth phase is acculturation (Akkulturation), i.e., settling snugly into the receiving culture. The sixth phase is indicative of postmodern societies: the deliberate preservation and maintenance of original cultural values (Punktuelle Bewahrung - Volskultur in der postmodernen Gesellschaft), but no longer with the intention of opposing them to those of the receiving culture (Tolksdorf 1990, 110-122).

Not less important to our inquiry are identity theories. The condition of being onself, the need to know who I am, what I am is a basic demand with the thinking human individual. The answer to these questions begins with the mother tongue (Péntek 2010, 161-162). Mother tongue as well as collective/national identity are central concerns in Lôrincz's book. Identity is another notion that cannot be captured in one single model, as different kinds of identities can be of different nature. The majority of European identities are typically citizenship-dependent. Székely-Hungarian identity alone is an extremely complex issue with tangled historical roots. ${ }^{5}$

It may not be an overstatement to say that the sense of individual and social identity has been foregrounded as a social sciences research topic in our days; the unprecedented wave of twenty-first century migration has certainly given it that prominence. Several disciplines - history, politics, social psychology and media studies among them - are making attempts at the interpretation of identity, also with the multiple forms it takes and the multiple roles it plays in multiple senses. Not to mention that identity formation in digital space is playing an ever increasing role in our age, with possible momentous and incalculable impact on both the human individual and social functions. In the literary text under discussion faceless communication taking place in digital space lends a special slant to the introduced state of affairs, contributing to the development of new forms of identity distortion or to the deepening of already existing identity crisis.

Ferenc Pataki defines identity as "the individual's position in the community. One can conceive of many kinds of identity: occupational, gender, family, nationstate etc. identity, depending on what kind of collective the individual belongs to" $(1986,9) .{ }^{6}$ It must be remarked here that cultural identity, Lőrincz's main concern, is most closely related to national identity. A simplified definition of cultural identity could be: common past history, native language, customs and traditions in which

$5 \quad$ The author devoted a book to this topic, especially to a typology that she set up to describe strategies of identity management in minority existence, see Dani (2016).

6 The translations from Hungarian literature and specialist literature are my own throughout the article. 
the individual is socialized. Pataki marks off five types of identity components: anthropological (gender, age, family and kinship relations, ethnic belonging); positional or role and group components (class and layer affinities, professional qualifications); identity components acquired through social-qualification activities and speech acts (legal procedures, categories of medical, cultural and statistical operations); ideologically-marked identity components (political, moral, religious factors); and ones that are emblematic in nature (name, physical features, symbols and fashions). Pataki argues that individual and collective elements of identity can be distinguished. Hierarchical arrangment of the just enumerated identity components can also be presumed, which is a manifestation of the individual's order of preference (Pataki 1986, 46-47).

Valér Veres regards minority identity as something special in a majority versus minority relationship. Giving voice to the idea of home country and homeland, national auto- and hetero-stereotypes, disposition towards the other nation, the great significance of history, national symbols, the role holidays play - all these are specific factors that strengthen the sense of identity. The road to understanding collective identity leads through individual identity, Veres suggests. As for individual socialization, we can make the distinction between two phases: primary and secondary socialization. As a result of the former, the individual becomes a member of society through the process of growing up and being educated; the latter positions the socialized individual in a new segment of society (Veres 2005, 15). Individual identity keeps changing in the course of life, it incorporates newer and newer elements, while discarding olthers. As far as the notion of collective identity is concerned, William Bloom's definition seems to be most adequate. Bloom's definition (based on Freud) marks off two kinds of identity: analytical and oedipal. The former stresses the role of financial allowances, while the latter is organized around the norms of "proper" behaviour - that is paternal standards that one is expected to measure up to (Bloom 1990, 51).

Jan Assmann's theory of cultural memory and identity is central to our thematic concern. He maintains that "[i]dentity is a matter of consciousness, that is of becoming aware of an otherwise unconscious image of the self. This applies both to individual and to collective life" $(2011,111)$. Identity has two forms: "I" identity and "we" identity. In the case of "I" identity "[a] self grows from the outside in. It builds itself up individually by participating in the interactive and communicative patterns of the group." "The collective "we' identity does not exist outside of the individuals who consitute [... ] it" (Assmann 2011, 111). "I" identity stresses the priority of the whole as opposed to the part, Assmann goes on to say, while "we" identity prefers the part to the whole. The part is subordinated to the whole "and only assumes its identity through the role that it plays within the whole, but the whole only emerges from the interplay between the parts" (Assmann 2011, 112). This is the double meaning of "sociogenic" and the basis 
of "sociogenesis." For the sake of a more subtle understanding of "collective or sociocultural identity," Assmann divides the "I"-frame into individual and personal identity $(2011,113)$ :

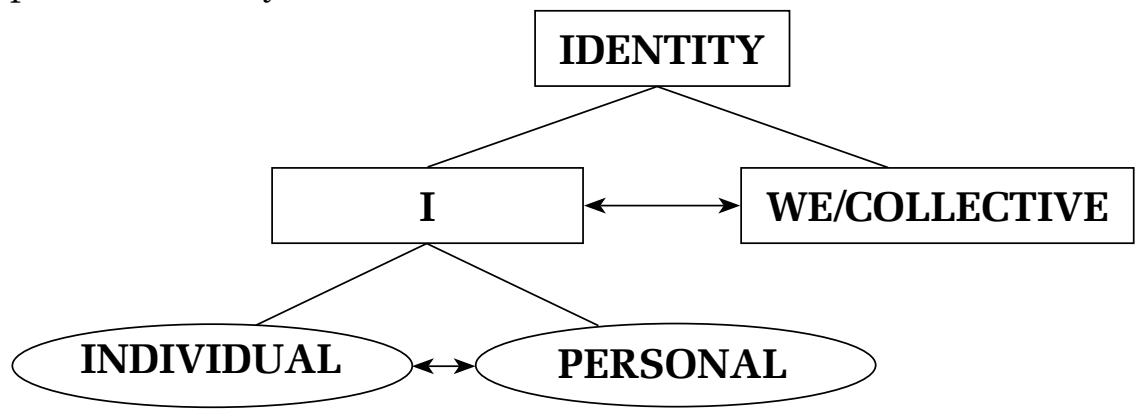

Individual identity "builds itself up in the consciousness of the individual" and relates to the bodily existence and the basic needs of the human being, whereas personal identity comprises the roles and talents that society demands from the individual. Both individual identity and personal identity "are determined sociogenically and culturally" (Assmann 2011, 113). "We" identity is "the image that a group has of itself and with which its members associate themselves" (Assmann 2011, 113-114). Thus collective identity is a matter of identification, it does not exist by itself. Its strength depends on how vivid it is in the consciousness of those who represent it, and to what extent that image can motivate the participants in their thinking and actions (Assmann 2011, 114). Identity can also be grasped in terms of crisis. As Imre Bori argues, "identity crisis is therefore the crisis of SELF-consciousness, loss of identity is indicative of the dissolution of SELF-consciousness" $(2000,310)$. This is why the individual needs to develop strategies of identity crisis management.

The nature of our topic also requires that we take note of the category of identity which Sándor Balázs called "minority identity." He posits it as a "spiritual structure" which exists in the subject's mind and takes shape in contents of consciousness. So its form of existence is human consciousness, but it can also prevail in a state of suspended animation, which is not fixed: it can be activated by external persons at any time. Its basic feature is "collective spiritual existence - in the consciousness of individuals or in a fixed form" (Balázs 1995, 18). Minority existence is an objective given: the Hungarians in Transylvania (but it is true of all Hungarians beyond the Trianon borders) never crossed the borders of their own country; rather, the borders crossed them. This objective factor also means, however, that it is "external to will and consciousness but interlaced with threads of the subjective" (Balázs 1995, 30). What arises from this is that no minority exists without the individual's positional awareness, nor does awareness of minority position exist without a minority situation. This "minority 
consciousness" is transposed into another frame when state borders are crossed in the case of the characters of the novel in question: the young individual in question, formerly coded as minority, crosses "the border" of her own free will, and becomes incapable of determining who she is within the same national culture since the minority situation in which she was socialized no longer applies.

\section{Sounds of the Heart and the Disintegration of Identity}

In Sounds of the Heart Lőrincz ${ }^{7}$ decided on a new subject, one which is rather unusual for him. Admittedly, the book is a "novel of love," in which "he meant to record the mother’s grief” (Lázár 2012). After novels like Pusztulás [Decay, 2005], Besúgó voltam, szívem [I Was an Informer, Dear, 2008] and Isten köve [God's Bolt, 2011], the title of the new novel seems light and - considering what the book is about - misleading. If defined in terms of our topic's terminology, Sounds of the Heart is a novel of identity crisis/distortion, of "borders" or boundaries in various senses as well as of the discourse between the culture of the mother nation and that of the population forced to live outside ("beyond") the mother nation's borders. It can also be interpreted as a diagnostic novel if we put migration, free movement as concomitant phenomena of globalization and permissive education with its consequences in the focus.

The story of Mária Réka Gordon and her daughter, Hanga, seems to be simply a contemporary sequence of events that could occur to anyone, the novel dissecting parent-child - more closely, mother-daughter - relationship. But it only seems to be. There is a third link, namely the figure of the father, Tamás Gordon, character whose apparently being pushed in the background plays a determining role in the web of interpersonal relationships, or rather, in the development of his daughter Hanga's somewhat Electra-like identity. Character relations are embedded in broader social contexts, and that aspect also involves, in the final analysis, the "image of decay," which we are accustomed to in Lőrincz's earlier works, and expect to be there, so to speak.

The life of the family of three living in a small town in Székelyland undergoes fundamental change the moment national borders become permeable following

7 György Lőrincz, the “Gyurka” of his Székelyudvarhely folk, was born at Kápolnásfalu (Harghita county, Székelyland, Transylvania, Romania) in 1946. This contemporary Székely-Hungarian writer works in his homeland, where he also organizes the literary, musical and artistic life of the region. He is a novelist, short story writer and essayist, who also does sociography, all devoted to issues related to Székelyland. Some significant works: Amíg csak él az ember [As Long as You Live, 1980], A hallgatás csöndje [The Silence of Being Silent, 1983], Bukás [Fall, 1995], Pusztulás [Decay, 2005], Besúgó voltam, szívem [I Was an Informer, Dear, 2008], A szív hangjai [Sounds of the Heart, 2012]. Awards: Székelyland Nívó Prize (2001), Székelyudvarhely Mayor's Honorary Diploma (2001), Szabó Zoltán Prize - a Hungarian Writers' Association award (2002), Hungarian Golden Cross of Merit (2016). 
"the revolution" (of 1989 - i.e. the collapse of the communist Ceauşescu regime) and the opportunity presents itself for everyone to make it to the "promised land" (of Hungary) beyond their reach before. But their ordinary life also changes in the sense that the opportunities afforded by a "boundless" (i.e. "borderless") world become available for their only daughter, Hanga. It happens when, owing to agegroup characteristics, she starts, naturally, to extricate herself from her limitations (widening her boundaries or "borders" as it were), asserting her independence from her parents, trying to understand a world that has broadened to an almost unnatural extent around her, as opposed to what was "natural" before.

The core story is woven around one single circumstance: the mother, who continues to live in the small Transylvanian town, launches a desperate search in Hungary, to find her vanished daughter in Budapest - a daughter who is deliberately fleeing from her mother and the home world she turned her back on. The writer works with alternating time levels, but the reader slowly assembles the picture. The girl, freshly graduated from the university in her homeland, decides to try her luck in the Hungarian capital. Her decision is motivated by rebellion: "Hanga's adaptable dutifulness to them too was nothing else than continuous, checked rebellion. Fear of authority" (Lőrincz 2012, 10). She protests against the parents' means of education (as it is natural with an adolescent), is intent on breaking away from the family and starting a life of her own. But she is not ready for that, neither in spirit nor regarding her sense of identity. At a dismal distance from home and homeland too, under the pressure of doubly different worlds Hungary for one, with the Budapest underworld on top of it - she takes the wrong turning and loses her footing.

The sequence and logic of events highlight the phenomenon of many Transylvanian youth becoming rootless between two post-'89 homelands (Transylvania in Romania, and Hungary). The young Transylvanian sets out in the conviction that the Hungarian capital is his or her spiritual-cultural-national centre too; the House of Parliament is his or her house of parliament too. Hanga rebels against her Székely "hick town," but is not "inoculated" against the reactions of disinheritance and denial with which the linguistically and culturally same (Hungarian) community of the motherland will relate to her. The moment of history offers Hanga the opportunity to cross borders, she tears up her roots, but then finds herself in the vacuum of boundlessness. And human voice knows no gravity: the loud-mouthed rebel girl becomes weightless, will be picked up by the wind and blown away.

Hanga Gordon's identity crisis, with its components, the cause-and-effect relations of its development, conveys to us an image of identity distortion, or, shall we say, deconstruction (deterioration) of identity, which is one of the points that the author - better to say, the narrator - very much wants us to pay heed to. The daughter wraps herself in "facelessness" and remains hiding in the background 
all through, availing herself of the advantages of the tools of digital technology when doing so. It is in this latter circumstance that the root of another evil lurks, one that is gaining greater and greater ground: the breakdown of communication in the world of communication as István Péter Szakács suggests in his review of the book. Hanga, who retreats into the virtual world, is a voice ("hang") ${ }^{8}$ which is falling silent; she beats off every attempt at approach, hurls accusations, calls to account, holds her parents responsible for her messed-up life: "I hate you because you wanted to love me and did not let me be who I am! You suffocated my nascent self with your love!” (Lőrincz 2012, 35). The field of the battle is internal here, in the souls, and in the proliferation of accusations and repartees that are wielded like weapons; there is an answer to every argument and to its counterargument too; as if the novel were also the psychology of harmony made impossible, rough interpersonal play and arguments pulled to pieces - all carried to an absurdity.

The Székely-Hungarian girl has no idea how dangerous the road she takes is when she "escapes" to the mother country. As already mentioned, she is not (and cannot be) ready for the world in which she arrives. She finds herself to be under double pressure. On the one hand, her national and cultural identity reach new dimensions, she has to redefine herself: this time not as minority in relation to a majority nation (as was the case in Romania) but in relation to the majority of her own nation (in Hungary). On the other hand, she is confronted with the circumstance that many motherland-Hungarians receive her with suspicion, or her otherness of the beyond-the-border Hungarian is even rejected. That is, she experiences what a good number of people had to endure in those years. Sounds of the Heart also offers a socio-psychological representation of this issue. Successful accommodation (in the case of Hanga), Milton Gordon would argue, would be possible "only" through social integration since we cannot talk about ethnic difference here. The young woman has already been awarded a degree, but does not yet represent the intelligentsia. What hinders successful structural assimilation is that she cannot (or does not want to) find a job suitable for her qualifications. When establishing ties with the Budapest underworld, she turns herself into a case of "undermigration" as it were, with social segregation at the end of the road. Nor can we talk about successful cultural assimilation in her case as the precondition to that would be attained structural assimilation. The values that underworld culture represents and the principles that regulate it are simply incompatible with the ones that would lend stability to Hanga's "we" identity. Most importantly, big-city underworld culture's opposition to the world offers her a "we" identity that can be no replacement for the value system of her Székely-Hungarian collective identity.

Hanga was socialized in minority existence. For her, national consciousness was what one opposed to the assimilating pressure of the Romanian majority nation.

"Hang," the Hungarian word for "voice," is incorporated in Hanga’s name. 
This definition of the self forms part of minority identity, an attitude towards life stemming from beyond-the-border objective reality. It is the phenomenon of "collective spiritual existence" described by Balázs, quoted above. The condition fixed in Hanga before is activated in a special way. Her minority identity remains the same nationwise, but is lodged in a new frame. As she crosses the now only symbolic state borders, her position as minority - which shaped and fixed her identity - ends. Moreover, she comes into contact with an otherness that practically forces the young girl to position herself with the subculture.

Besides the presure of minority existence, being a Szekler is also coupled with the sustaining power of the community, a collective or "we" identity, as Assmann would have it, which secures a symbiotic existence for "I" identity and to the individual and personal segments that the latter comprises. The sociogenic and cultural determination of the components of "I" identity are of crucial importance in Hanga's case. The individual component of the young woman's "I" identity is thrown off balance in the course of her struggle with herself and with her parents when - as one result of her "rebellions" - she encounters the underworld, which sucks her in as it were. Her identity crisis really dates from the point when "the male companion" appears in her life, and this companion is an embodiment of the globalized world's subculture. The narrator does not provide details other than flashes of some images sometimes, such as images of alcohol, drug, ecstasy, prostitution, the underworld. This is the point where Hanga's individual identity reels as subcultural solutions take over in the realm of her basic needs, the pitfall is that of cultural determination:

I was testing my limits. The limits of my personality [...] There was some fatal desire, how far I can push my own boundaries! The borders of my self! [...] Those were fateful days! It was then that it started to spread in high schools, that, for want of something better, it became fashionable to drink spirits after various kinds of pills at school parties. We were seeking ecstasy against the greyness of our life, wanted to dream, since we did not even have dreams when sober, and started to pursue pleasures. (Lőrincz 2012, 36)

The individual segment losing balance does not yet involve confusion in the individual's "I" identity since its other "pillar" can continously compensate, not mentioning the sustaining power of collective "we" identity that surrounds the individual in his or her environment. There is nothing particular in Hanga attempting to find herself, testing her own limits: it is characteristic of the youth of welfare societies. The crisis of confused identity turns really serious when the

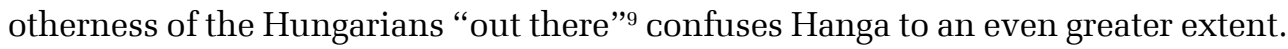

9 For beyond-the-border, minority Hungarians the mother country (Hungary) is "out there." 
Add to that the result of "the December referendum," ${ }^{10}$ which comes as a blow on her national identity. She perceives the devaluation of her "Transylvanianness" anyway: "it is not easy to be a Hungarian here either, only you would not understand this! You have been feeding me with hopes your whole life, talking to me about being a Hungarian, and behold! I wish you could see how they look at me!” (Lőrincz 2012, 24) - she writes to her parents at home. This further foments rebellion in her, so much so that she tramples on her parents' Hungarianness in a sickening manner: "But I may go back home and marry a Romanian! Then my father will have a reason to cry and can dance the hóra!" (Lôrincz 2012, 24). ${ }^{11}$ What that means if a remark like that is made by a child in a Székely family cannot be gauged by a Hungarian who lives in Hungary; you can feel that such a remark is like a dagger in your heart only if you were socialized in Székelyland. This is the circumstance that shakes the other pillar (the personal segment) of her "I" identity undermining the solidity of her identity for good. Hanga's sense of national identity comes under an "attack" against which the identity code ${ }^{12}$ that worked well in minority existence up to the point when she crossed borders out of Romania and into Hungary, loses validity, the balance of her "I" identity is tipped. She then subjects herself to a process of subordination almost involuntarily.

The situation becomes irreversible and final, when, again, the Székelyland Hungarian girl's "I" identity loses support of its "helper," "we" identity. The supportive role of collective, "we" identity that fulfilled its function within the Székelyland framework back home, is now eliminated in what can be regarded as the same culture. Her new situation can be conceived of as just another minority position. Hungarian collective minority identity is replaced with Hungarian big-city underworld subculture. What this process yields can only be what the novel projects: Hanga becomes a rootless drifter. Immediately relevant here, as explanatory of the process, is the presence or absence of identity components outlined by Pataki in what is happening to Hanga's individual identity. The young woman's anthropological and positional identity components become practically dysfunctional, and only the political factors of the idelogical group remain: moral and religion no longer count. On the other hand, identity components of emblematic nature will be foregrounded - e.g. symbols, fashions, physical distinctive marks which help her integration into underworld identity.

Hanga Gordon's identity tribulations are innate in origin, but her rebellious efforts to transcend her boundaries, stirred by external circumstances, catalyze the

10 December 5, 2004 was the day of Hungary's abortive referendum on whether Hungarians beyond the border may or may not be granted Hungarian citizenship. The referendum was abortive because it resulted in a denial of Hungarian citizenship to Hungarians beyond the border, so it goes down in Hungarian history as a historical trauma.

11 "Hóra" is a Romanian national round dance.

12 By "identity code" I mean being coded through primary socialization; in the present case, minority socialization. 
process and bring it to completion. All this leads to her finding herself inside the broad interpretive/misinterpretive framework of motherland-Hungarian/Székely Hungarian/"mock Hungarian" (próbamagyar), thereby losing the ground from under her feet, and her fate is left open in the book. Her case illustrates the first, segregation phase of Hess's integration model. Hanga ends up on the periphery of motherland society, thus in a state of segregation. But it is only the first step, after which her accommodation is continued in a subsocial layer; her personal identity reels to yield to the norms and values of subculture to which she consciously succumbs. The writer does not travel this road any farther, apparently abstains from the detailed description of the further phases of accommodation. But the closing scene of the novel, in which the mother also seems to be claimed by Budapest subcultural mess, is a tough and merciless memento. Chaos takes over; there is no answer in the end, no hope. If this turn of events is not developed any further in the present paper, it is because the novel itself intends it to be a provocative, not a little baffling closure, an open ending that leaves the rest to the reader. One thing is certain: lioness-mother Mária Réka is sucked in and swept away by cultural chaos.

In the strict sense of the word, the Székely-Hungarian girl becomes an "immigrant." She is an immigrant in a country of which her forefathers used to be citizens with full powers, and the contemporary citizens of which, the majority in a referendum at the dawn of the twenty-first century, denied beyond-the-border Hungarians Hungarian citizenship. Hanga is torn by moral, existential, and identity conflicts. Her identity problem is grounded in the sense of "becoming nobody" (Kapitány-Kapitány 1996, 82). Hanga arrives in a nativelanguage environment, but her integration is impeded by delicate signals of the surrounding culture that she is unable to decode. It feels as if she were "banished" since her accommodation is hampered by the disadvantages she has brought along from her homeland culture: a lower degree of self-assurance, lack of information. What intensifies it all is the pressure of "double alienness" (Kapitány-Kapitány 1996, 83), because her journey is from a Székelyland minority position - defined as "alien," "other" by the dominant (Romanian) culture - to one that also gives her the sense of being an alien. Her feelings could be diagnosed as Tolksdorf's cultural shock for that matter. She does not move through all the Tolksdorfian stages, getting stuck at the level of cultural shock, never reaching the stage of rebuilding herself and her national as well as cultural identity that could enable her to reach further stages and even to find again her healthy self perhaps. Not to mention the point that to proclaim and preserve origin and value consciously (Tolksdorf's sixth stage) is a prevalent practice in postmodern societies of our age. 


\section{Conclusion}

Lőrincz's novel is a social diagnosis. It addresses issues that are highly relevant for, and can be helpful to, the responsible reader in relating to the vicissitudes of identity management in the turbulent world of the early twenty-first century. It is especially important in a life that moves in an accelerated, digital space, in which our youth are becoming rootless and aimless more and more and their problems of self-definition cry for solutions. One decisive phenomenon of our days is internal migration inside Europe, which contributes to the undisrupted functional order of European societies only if, for one, the identity of those who set out will not disintegrate in the process.

Hanga Gordon is a typical example of identity disintegration or deconstruction. The process is gradual, layered, and its direction is from the internal towards the external. Her basic problems stem from the minority form of existence: her "I" identity wavers when her testing of her "boundaries," while growing up, opens a window for her onto the world, onto a subculture which offers attractive solutions for a personality that has not quite taken shape yet. The way the parents - in a small-town Székely family of closed communication and ridden with interpersonal conflicts in the first place - react when they sense deviant behaviour does not help the situation. Unintentionally, they will contribute to the deepening of their child's identity troubles. As, naturally, the two parents' own identity was shaped by, and fixed in, minority existence, the deficiencies of that identity also do contribute to what happens. The "limits" of liberal education, the absence of Christian traditions, the socialist-state establishment of decades with its repressive and atheistic ideology all played their important roles in this development.

So the trouble starts with the breakdown of Hanga's individual identity and continues in her personal segment. As her identity deconstructs itself, she is pushed right into the phase of segregation, onto the periphery of a same culture, losing the support of "we" identity (of the Székelyland community). At the same time, she comes under the influence of another "we" identity (that of the Hungarian underworld), only to have both segments of her "I" identity transformed as a result of a process that grows from inside out. The cultural determination of the new "we" identity is different, it re-codes individual and personal identity, thus driving the "rootless" young, who lost parents, home and homeland, through the phase of acculturation, towards integration. She has no need for mimicry as she does not want to hide and has nothing left to fear of: her cultural identity is no longer a question in the world that sucks her in.

Lőrincz presents the problem but offers no answer. What is more, he outright provokes us with the closing scene of the novel, in which moral nihility drags down the "lion mothers" of the Mária-Réka kind with the floating Hangas. We may 
justly suppose that Lőrincz means to communicate something else to the reader: there is more to it than the "mock Hungarian" getting into hot water; rather, a new world that knows no bounds (in any sense) has arrived to re/transcode whole generations?

The social phenomenon we are facing here is that thousands of Transylvanian youth are seeking to make their way, to be successful far from their homeland, either in the mother country of Hungary or in other countries in Western Europe. Assimilation in the same culture seems to be more evident for a superficial examiner of the question. But is it really the case? We may have a clearer vision of the issue, a better understanding of what is taking place through studying the Hanga-phenomenon of Lőrincz's novel.

\section{Works Cited}

Assmann, Jan. 2011 [1992, 2007]. Cultural Memory and Early Civilization: Writing, Remembrance, and Political Imagination. Trans. David Henry Wilson. Cambridge: Cambridge University Press. [Originally published as Assmann, Jan. 1992. Das kulturelle Gedächtnis: Schrift, Erinnerung und politische Identität in frühen Hochkulturen. München: Verlag C. H. Beck.]

Balázs, Sándor. 1995. Identitástudatunk zavarai. [Identity Disorders.]. Bucharest: Kriterion.

Bloom, William. 1990. Personal Identity, National Identity and International Relations. Cambridge: Cambridge University Press.

Bori, Imre. 2000. Identitáskeresóben. [In Search of Identity.] Novi Sad: Forum.

Cseresnyés, Ferenc. 2005. Migráció az ezredfordulón. [Migration at the Turn of the Millennium.] Budapest-Pécs: Dialóg Campus.

Dani, Erzsébet. 2016. Identitásgyarmatosítás Erdélyben: identitásdrámák és interkulturális stratégiák a Trianon utáni székelymagyar irodalomban. [Identity Colonization in Transylvania: Identity Dramas and Intercultural Strategies in Post-Trianon Székely-Hungarian Literature.] Miercurea Ciuc: Pro-Print.

Gyurgyík, László. 2011. “Az asszimiláció szociológiai elméleteinek és operacionalizálásuknak egy lehetséges változata a társadalomtudományi kutatásokban." ["A Possibile Version of the Sociological Theories of Assimilation and Their Operationalization in Social Science Research."] In Politika és nemzeti identitás Közép-Európában [Politics and National Identity in Central Europe], eds. Nándor Bárdi and Gábor Lagzi, 149-162. Budapest: Teleki László Alapítvány.

Hess, Beth Bowman. 1988 [1982]. "Processes in the Integration of Minority Groups.” In Sociology. Third edition, eds. Beth B. Hess, Elizabeth W. Markson and Peter J. Stein, 247-249. New York: Macmillan Publishing Company. 
Kapitány, Ágnes and Gábor Kapitány. 1996. "Kultúrák találkozása - kultúraváltás.” [“Cultures Meeting - Changing Cultures.”] In Táborlakók, diaszpórák, politikák [Camp-Dwellers, Diasporas, Policies], 67-91. Budapest: MTA Politikai Tudományok Intézete.

Lázár, Emese 2012. "Aki megírta a szeretet könyvét." ["The One Who Wrote the Book of Love."] http://uh.ro/kultura/irodalom/11116-aki-megirta-a-szeretetkonyvet. (Last accessed 17 March 2015)

Lőrincz, György. 2012. A szív hangjai. [Sounds of the Heart.] Miercurea Ciuc: Pro-Print.

Pataki, Ferenc. 1986. Identitás, személyiség, társadalom. [Identity, Personality, Society.] Budapest: Akadémiai.

Péntek, János. 2010. “Anyanyelv és identitástudat." ["Mother Tongue and Identity."] Debreceni Szemle vol. 18 no. 3: 160-168.

Sík Endre. 1996 [1990]. "Erdélyi menekültek Magyarországon.” [“Transylvanian Refugees in Hungary."] In Társadalmi riport 1996 [Social Report 1996], eds. Rudolf Andorka, Tamás Kolosi and György Vukovich, 516-533. Budapest: TÁRKI.

Szakács, István Péter. 2012. http://www.barkaonline.hu/olvasonaplo/2987-asziv-hangjai. (Last accessed 17 March 2015)

Tolksdorf, Ulrich. 1990. "Phasen der kulturellen Integration bei Flüchtlingen und Aussiedlern.” In Neue Heimat im Westen: Vertriebene, Flüchtlinge, Aussiedler, ed. Klaus J. Bade, 106-127. Münster: Westfählischer Heimatbund.

Veres, Valér. 2005. Nemzeti identitás Erdélyben: szociológiai olvasatban. [National Identity in Transylvania: A Sociological View.] Budapest: Akadémiai Kiadó.

Yinger, John Milton. 1981. "Toward a Theory of Assimilation and Dissimilation [sic].” Ethnic and Racial Studies vol. 4 no. 3 (July): 249-264. 